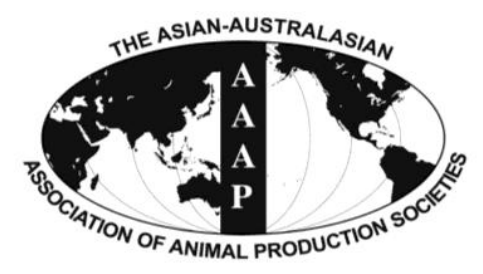

Asian-Aust. J. Anim. Sci.

Vol. 26, No. 2 : 202-210 February 2013

http://dx.doi.org/10.5713/ajas.2012.12442

www.ajas.info

pISSN 1011-2367 elSSN 1976-5517

\title{
Limiting Concentrate during Growing Period Affect Performance and Gene Expression of Hepatic Gluconeogenic Enzymes and Visfatin in Korean Native Beef Calves
}

\author{
S. S. Chang, J. D. Lohakare ${ }^{1}{ }^{*}$, N. K. Singh ${ }^{1}$, E. G. Kwon, J. G. Nejad ${ }^{1}$, K. I. Sung ${ }^{1}$ and S. K. Hong \\ Hanwoo Experimental Station, National Institute of Animal Science, RDA, Pyeongchang, Korea
}

\begin{abstract}
This study elucidated the effects of limited concentrate feeding on growth, plasma profile, and gene expression of gluconeogenic enzymes and visfatin in the liver of Hanwoo beef calves. The purpose of this study was to test that reducing the amount of concentrate would partially be compensated by increasing the intake of forage and by altering the metabolic status. The study utilized 20 Korean native beef calves (Hanwoo; 60 to $70 \mathrm{~d}$ of age) divided into two groups of 10 calves each for $158 \mathrm{~d}$. Control group calves received the amount of concentrate as per the established Korean feeding standards for Hanwoo, whereas calves in the restricted group only received half the amount of concentrate as per standard requirements. Good quality forage (Timothy hay) was available for $a d$ libitum consumption to both groups. Since calves were with their dam until 4 months of age in breeding pens before weaning, the intake of milk before weaning was not recorded, however, the concentrate and forage intakes were recorded daily. Body weights (BW) were recorded at start and on $10 \mathrm{~d}$ interval. Blood samples were collected at start and at $50 \mathrm{~d}$ interval. On the final day of the experiment, liver biopsies were collected from all animals in each group. The BW was not different between the groups at all times, but tended to be higher $(\mathrm{p}=0.061)$ only at final BW in control than restricted group. Total BW gain in the control group was $116.2 \mathrm{~kg}$ as opposed to 84.1 $\mathrm{kg}$ in restricted group that led to average BW gain of $736 \mathrm{~g} / \mathrm{d}$ and $532 \mathrm{~g} / \mathrm{d}$ in respective groups, and the differences were significant $(\mathrm{p}<0.01)$. As planned, the calves in the control group had higher concentrate and lower forage intake than the restricted group. The plasma variables like total protein and urea were higher $(\mathrm{p}<0.05)$ in control than restricted group. The mRNA expressions for the gluconeogenic enzymes such as cytosolic phosphoenol pyruvate carboxykinase (EC 4.1.1.32) and pyruvate carboxylase (EC 6.4.1.1), and visfatin measured by quantitative real-time PCR in liver biopsies showed higher expression $(\mathrm{p}<0.05)$ in restricted group than control. Overall, restricting concentrate severely reduced the growth intensity and affected few plasma indices, and gene expression in liver was increased indicating that restricting concentrate in the feeding schemes during early growth for beef calves is not advocated. (Key Words: Calf, Concentrate, Growth, Gluconeogenic Enzymes, Plasma)
\end{abstract}

\section{INTRODUCTION}

In calf rearing systems, an early and high intake of concentrate and roughage is encouraged to reduce the milk rearing or milk replacer feeding costs and to ensure a better development of the forestomachs. Additionally, the beef cows do not produce enough milk approximately after $90 \mathrm{~d}$ of lactation to meet the nutrient requirements of the calf due to its rapid growth. Glucose homeostasis is considered a crucial determinant of metabolic status that affects the performance of beef calves around weaning. To minimize

\footnotetext{
* Corresponding Author: J. D. Lohakare. Tel: +82-33-250-8633, Fax: +82-33-251-7719, E-mail: jayant@kangwon.ac.kr

${ }^{1}$ College of Animal Life Sciences, Kangwon National University, KNU Ave 1, Chuncheon 200-701, Korea.

Submitted Aug. 16, 2012; Accepted Oct. 10, 2012; Revised Oct. 29, 2012
}

the adverse consequences of glucose shortage, nutritional strategies to improve glucose homeostasis is an important area of research in calves around weaning.

The effects of age, weaning, and different diets, especially in early weaning production systems on metabolic changes and physiological adaptation is not well understood in ruminants. Glucose serves as the main energy source in neonatal and pre-ruminant calves, but the lactose intake/milk intake does not meet glucose demands in very young calves (Girard et al., 1992). Also, the reduction in milk intake and the introduction of solid food cannot meet glucose demands; hence for carbohydrate homeostasis, glycogenolysis and gluconeogenesis become important in the liver (Girard et al., 1992; Hammon and Blum, 1998; Haga et al., 2008). Feeding and managing calves is expensive, requires extensive labour and contributes 
significantly to farm expenses.

Energy intake could be controlled by limit-feeding a more nutrient dense diet. Limit-feeding may reduce feed cost and manure nutrient excretion which is recently of great concern in the animal industry (Hoffman et al., 2007). Restricting concentrate reduces energy intake, nutrient excretion and feed cost. On the other hand feeding low energy, high-fibre forages effectually controls energy intake (Hoffman et al., 2007). It has also been known for some time that diets containing high proportions of concentrate are utilized with greater efficiency than those containing high proportion of forages (Garrett, 1979).

Visfatin, an adipokine, is a metabolically important protein that plays important role in insulin sensitivity, glucose homeostasis and lipid metabolism (Fukuhara et al., 2004; Lemor et al., 2009). No studies have been reported yet in calves on its role in glucose homeostasis around weaning. The hypothesis of this study was that reducing the amount of concentrate would partially be compensated by encouraging the intake of forage, leading to a moderate decrease of the growth intensity of the beef calves but possibly also altering the metabolic status. Our earlier study in dairy calves showed that restricting concentrate from 2 $\mathrm{kg} /(\mathrm{calf} \times \mathrm{d})$ to $1 \mathrm{~kg} /(\mathrm{calf} \times \mathrm{d})$ moderately reduced the growth intensity without affecting serum indices and gluconeogenic enzymes expression in liver (Lohakare et al., 2012). The present study evaluated the effect of limited concentrate feeding on growth performance, plasma variables, and mRNA expression of gluconeogenic enzymes and visfatin in the liver of Korean native (Hanwoo) beef calves.

\section{MATERIALS AND METHODS}

\section{Animals, housing and feeding trial}

Twenty 60 to $70 \mathrm{~d}$-old Korean native beef calves (Hanwoo) were utilized for the experiment at Hanwoo Experimental Station, a research farm of National Institute of Animal Science, Pyeongchang, Kangwon province, South Korea. The calves were randomly divided into 2 groups based on BW. Each group consisted of 7 male and 3 female calves. The calves in both groups received milk from their respective dams until weaning at 4 months of age according to the scheme established on the farm. The farm had a facility where the dams and calves of each group could be reared separately under the same shed until weaning. The calves had free choice to meet their respective dam or stay in stalls where dam could not enter. The calves were reared in different groups with their mother in the breeding pens during the pre-weaning stage and then separated from their dam post-weaning. In pre-weaning stage, there was no access of the dam to the calf pen when feeds were given.

Control group calves received the amount of concentrate as per the established feeding standards for Hanwoo calves (Korean Feeding Standards for Korean Cattle (Hanwoo), 2002), whereas calves in the restricted group only received half the amount of concentrate as per standard requirements. In addition, calves had ad libitum access to timothy hay before and after weaning along with their allocated portion of concentrate. The calves were offered weighed quantities of hay. The quantity of hay offered was adjusted to about $120 \%$ of the previous day's intake throughout the trial. Feed residues, if any, were weighed the following day before offering fresh hay in order to determine the daily voluntary intake of forage for each group.

The ingredient composition of the concentrate fed to both groups is given in Table 1 together with analyzed chemical composition of the concentrate and hay. Clean drinking water was available to the calves all the time. The animals were maintained on the above feeding schedule for $158 \mathrm{~d}$. The calves in each group were housed in well ventilated and cement-floored breeding pens with straw as bedding material with their dams during pre-weaning stage as mentioned earlier. Concentrate and hay were offered manually. Calves were dewormed at the start by using broad-spectrum anthelmentics and were vaccinated against prevalent contagious diseases.

The BW of individual calves were recorded at start and at $10 \mathrm{~d}$ interval until $158 \mathrm{~d}$ of the trial in the morning before

Table 1. Ingredients of the concentrate $(\mathrm{g} / \mathrm{kg})$ and composition ( $\mathrm{g} / \mathrm{kg}$ dry matter unless stated) of concentrate and timothy hay

\begin{tabular}{lrr}
\hline Ingredients & Concentrate & Timothy hay \\
\hline Maize & 160 & \\
Wheat & 230 & \\
Coconut kernel meal & 60 & \\
Maize gluten feed & 50 & \\
Wheat bran & 230 & \\
Rice bran & 10 & \\
Palm kernel expeller & 60 & \\
Canola meal & 30 & \\
Rape seed meal & 20 & \\
DDGS & 50 & \\
Limestone & 20 & \\
Molasses & 30 & \\
Mineral-vitamin mixture & 50 & \\
Composition & & \\
Dry matter (DM, g/kg) & 881 & \\
Crude protein & 166 & 931 \\
Ether extract & 45 & 93 \\
NDF & \\
ADF & 343 & 664 \\
Ash & 123 & 418 \\
Ca & 95 & 107 \\
P & 12 & 2 \\
\hline
\end{tabular}

${ }^{1}$ Neutral detergent fibre, expressed with residual ash.

${ }^{2}$ Acid detergent fibre, expressed with residual ash. 
feeding, in order to assess changes in BW and average daily gain (ADG). The animal experimental procedure and methods were approved by the animal welfare and ethics authority of Kangwon National University, Chuncheon.

\section{Blood collection and analysis}

Blood samples were collected from all animals in each group in the morning at $08.00 \mathrm{~h}$ before the feed was offered at $\mathrm{d}$ 0,50,100 and 158 of the trial from a jugular vein into tubes, with heparin as an anticoagulant. The anticoagulated blood samples were centrifuged at $1,200 \mathrm{~g}$ for $20 \mathrm{~min}$ at $4^{\circ} \mathrm{C}$ to separate the plasma. The plasma samples were stored at $-20^{\circ} \mathrm{C}$ until further analysis for glucose, total protein, albumin, urea, triglycerides, amylase (EC: 3.2.1.1), aspartate aminotransferase (AST; EC: 2.6.1.1), and alanine aminotransferase (ALT; EC: 2.6.1.2).

\section{Analyses in feed}

The proximate analysis of feeds was performed according to official methods of AOAC (1997). The DM of feedstuffs was determined by drying at $105^{\circ} \mathrm{C}$ and organic matter $(\mathrm{OM})$ was estimated by ashing at $550^{\circ} \mathrm{C}$ overnight $(\mathrm{OM}=\mathrm{DM}$-ash). The $\mathrm{N}$ was determined using the standard Kjeldahl procedure using $\mathrm{Cu}^{2+}$ as a catalyst and $\mathrm{CP}$ was calculated as $\mathrm{N} \times 6.25$. Feed samples were analyzed for neutral detergent fibre (NDF; Van Soest et al., 1991) and acid detergent fibre (ADF, AOAC, 1997; method 973.18) and expressed with residual ash.

\section{Liver biopsy collection and gene expression analysis}

Liver biopsy collection: Liver biopsies were collected at d 158 of the trial from all animals in each group according to the procedure of Swanson et al. (2000). Briefly, the calves were restrained and sedated $20 \mathrm{~min}$ prior to the procedure and placed in left-lateral recumbency. The right caudo-thoracic area at an intercostal space between the 10th and 11th rib approximately $16 \mathrm{~cm}$ from the dorsal midline was shaved and washed with liquid disinfectant. Using local anaesthetics, a small incision $(0.8 \mathrm{~cm})$ in the skin was made with a surgical blade. The biopsy trocar was inserted through the incision penetrating the subcutaneous tissues, peritoneum and introduced in the liver parenchyma and samples from 3 different locations were collected at the same time. Around 500 to $600 \mathrm{mg}$ wet sample weight were collected. After biopsy, the skin incision was applied with antiseptic agent and treated as an open wound until healed. It took 2 to $4 \mathrm{~h}$ for calves to stand after biopsy and no complications due to biopsy procedure were observed in any calf.

Liver biopsy samples were collected in screw capped tubes and transferred in liquid nitrogen to the laboratory and stored at $-80^{\circ} \mathrm{C}$ until measurement of mRNA expression of gluconeogenic enzymes, namely cytosolic phosphoenol pyruvate carboxykinase (PEPCK-C; EC 4.1.1.32) and pyruvate carboxylase (PC; EC 6.4.1.1), and visfatin by quantitative real-time polymerase chain reaction (qPCR).

RNA isolation: For mRNA quantification, TRIzol reagent (Sigma-Aldrich, Seoul, Korea) was used for extracting total RNA. Briefly, frozen liver tissue was ground in liquid $\mathrm{N}$ and 20 to $30 \mathrm{mg}$ was used for extraction. TRIzol reagent was added and RNA was isolated according to the protocol of the supplier, followed by DNase digestion in solution using RNase-free DNase set (Qiagen, Seoul, Korea). Total RNA purification was performed using RNeasy Mini Kit (Qiagen). The quality of the purified RNA was tested by measuring optical density ratios at 260 and $280 \mathrm{~nm}$ and also by gel electrophoresis using ethidium bromide as stain.

Synthesis of complementary deoxyribonucleic acid ( $c D N A)$ : The synthesis of cDNA was performed using 1.8 $\mu \mathrm{g}$ of total RNA with Revert Aid reverse transcriptase (RT) (Fermentas, St.Leon-Rot, Germany) and 50 pmol random hexamer primers (Sigma-Aldrich). No-RT controls were created by omitting reverse transcription. No-template controls were created by adding nuclease-free water.

Quantification of $m R N A$ : The amount of mRNA of the different candidate genes was quantified using qPCR (Cycler Mx 3000P, Stratagene, Amsterdam, The Netherlands) as reported by Lemor et al. (2009). The features of the primers used for quantification are presented in Table 2. For PEPCK-C, PC and glyceraldehyde phosphate dehydrogenase (GAPDH) the primers were used as mentioned by Hammon et al. (2003) and Lohakare et al. (2012). For visfatin, the primers were developed by using the primer3 program. Copy numbers for each transcript were calculated from standard curves, based on purified and sequenced amplicons. Melting curve analysis confirmed the presence of a single product for qPCR assay. The reaction was performed in a total volume of $10 \mu \mathrm{l}$ composed of $2 \mu \mathrm{l}$ of template diluted 1:4,1 $\mu$ l of the assay-specific primer mix, $5 \mu$ l of the SYBR Green JumpStart Taq Readymix (Sigma-Aldrich), and $2 \mu$ double-distilled water. All samples were measured in triplicate. No-template controls were performed using nuclease-free water. In addition, noRT and no-template controls from the cDNA synthesis were used to check for contamination.

Mean cycle threshold $\left(\mathrm{C}_{\mathrm{t}}\right)$ values of triplicate test samples and triplicate control group samples were used for statistical analysis. The delta $\mathrm{C}_{\mathrm{t}}\left(\Delta \mathrm{C}_{\mathrm{t}}\right)$ values were calculated after subtracting the mean $C_{t}$ values of GAPDH gene from the genes of interest and then the expression was calculated by delta delta $C_{t}$ method as suggested by Livak and Schmittgen (2001).

\section{Statistical analysis}

The data generated during the study were analyzed using one way analysis of variance. The means were 
Table 2. Primer sequences and conditions used for $\mathrm{qPCR}$

\begin{tabular}{|c|c|c|c|c|c|}
\hline Name & $\begin{array}{l}\text { Forward primer sequence }\left[5^{\prime}-3^{\prime}\right] \\
\text { Reverse primer sequence }\left[5^{\prime}-3^{\prime}\right]\end{array}$ & Acc. No. ${ }^{1}$ & Len $(b p)^{2}$ & $\mathrm{Ta}\left({ }^{\circ} \mathrm{C}\right)^{3}$ & Cycles \\
\hline${\mathrm{PEPCK}-\mathrm{C}^{4}}^{4}$ & $\begin{array}{l}\text { GACGGCCTCAACTACTCAGC } \\
\text { TTGATCACACCCTCCТCCTC }\end{array}$ & NM174737 & 182 & 60 & 40 \\
\hline $\mathrm{PC}^{5}$ & $\begin{array}{l}\text { ATCTCCTACACGGGTGACGT } \\
\text { TGTCGTGGGTGTGGATGTGCA }\end{array}$ & NM177946 & 214 & 60 & 40 \\
\hline Visfatin & $\begin{array}{l}\text { CAGGCACCACTAATAATCAGAC } \\
\text { CAGCAACTTGTAACCCTTTGAG }\end{array}$ & NM182790 & 120 & 60 & 40 \\
\hline $\mathrm{GAPDH}^{6}$ & $\begin{array}{l}\text { AATGGAAAGGCCATCACCATC } \\
\text { GTGGTTCACGCCCATCACA }\end{array}$ & U85042 & 204 & 60 & 40 \\
\hline
\end{tabular}

${ }^{1}$ Acc. No., Accession number. ${ }^{2}$ Len $(b p)=$ Fragment length (base pairs). ${ }^{3}$ Ta $=$ Annealing temperature.

${ }^{4}$ PEPCK-C =Phosphoenol pyruvate carboxykinase-cytosolic. ${ }^{5} \mathrm{PC}=$ Pyruvate carboxylase.

${ }^{6} \mathrm{GAPDH}=$ Glyceraldehyde phosphate dehydrogenase.

Table 3. Average daily feed intake per calf during the feeding trial

\begin{tabular}{lcc}
\hline $\begin{array}{l}\text { Average daily feed }(\mathrm{DM}) \\
\text { intake per calf }\end{array}$ & \multicolumn{2}{c}{ Treatment } \\
\cline { 2 - 3 } Concentrate $(\mathrm{kg} / \mathrm{d})$ & 1.72 & Restricted \\
Timothy hay $(\mathrm{kg} / \mathrm{d})$ & 1.52 & 0.86 \\
Total $(\mathrm{kg} / \mathrm{d})$ & 3.24 & 1.73 \\
Crude protein $(\mathrm{kg} / \mathrm{d})$ & 0.427 & 2.59 \\
Concentrate: Roughage & 1.13 & 0.304 \\
\hline
\end{tabular}

subjected to test of significance by Tukey's test using Statistical Package for Social Sciences (SPSS 16.0 version). For plasma variable analysis, group and time (period) were fixed effects and animals were treated as random effects. When an interaction was observed between main effects, the period effect was further separated using the TUKEY adjustment. Differences among means with $\mathrm{p}<0.05$ were accepted as representing statistically significant differences and differences among means with $0.05<\mathrm{p}<0.10$ was accepted as representing tendencies to differences.

\section{RESULTS}

\section{Feed intake}

Average daily intake of the concentrate mixture per calf
Table 4. Body weight changes in Hanwoo calves

\begin{tabular}{lcccc}
\hline & Control & Restricted & SEM $^{1}$ & p-value \\
\hline Initial BW $(\mathrm{kg})$ & 61.6 & 61.2 & 3.12 & 0.951 \\
Final BW $(\mathrm{kg})$ & 177.8 & 145.3 & 8.77 & 0.061 \\
BW gain $(\mathrm{kg})$ & 116.2 & 84.1 & 6.59 & 0.010 \\
ADG $(\mathrm{kg})$ & 0.736 & 0.532 & 0.042 & 0.010 \\
\hline${ }^{1}$ Standard error of means. & & &
\end{tabular}

was as intended (Table 3), showing a lower concentrate intake in the calves of the restricted group than the control. Similarly, and as expected, the average daily forage intake per calf was higher for the restricted than the control group. The average daily DM intake per calf was higher in control than restricted group (Table 3).

\section{Body weight changes and growth}

The BW of the calves at start and at all measurements was not different $(p>0.05)$ between the groups, but tended to be higher $(\mathrm{p}<0.061)$ only at final $\mathrm{BW}$ in control than restricted group (Table 4, Figure 1). The BW gain in control calves was $32 \mathrm{~kg}$ higher than those of the restricted calves at the end which turned out to be significant $(\mathrm{p}=0.01)$. The ADG was $736 \mathrm{~g} / \mathrm{d}$ in the control group, which was also greater $(p=0.01)$ than the ADG of calves in the restricted

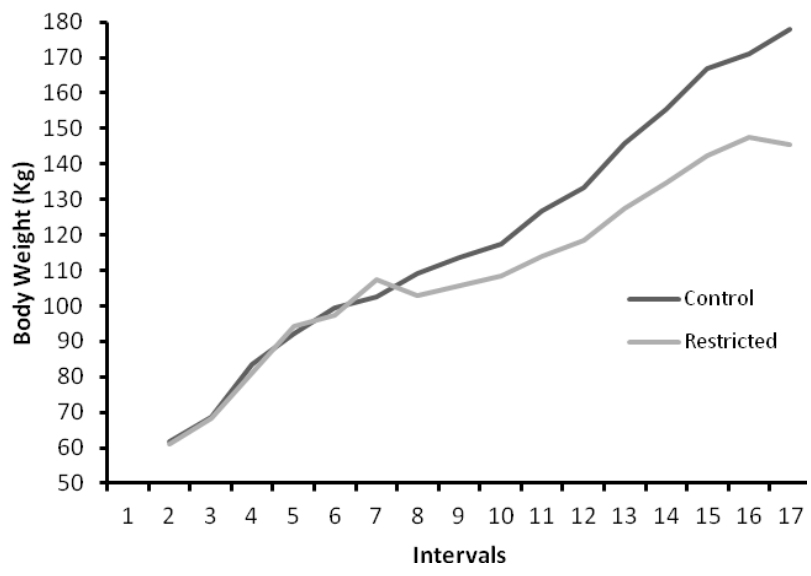

Figure 1. Body weight changes in calves at approximately $10 \mathrm{~d}$ intervals. 
group $(532 \mathrm{~g} / \mathrm{d})$.

\section{Analyses in blood}

The plasma levels of glucose did not differ between the groups (Figure 2a). The plasma glucose levels were lower $(\mathrm{p}<0.001)$ at $\mathrm{d} 50$ than at other days showing period effects, however, no interaction effect occurred between groups and periods.

The plasma levels of total protein varied due to dietary treatments (Figure 2b), showing higher $(\mathrm{p}<0.05)$ levels in control than restricted group. Period effect was observed for the plasma levels of total protein showing lower levels at $\mathrm{d}$ 100 than at d 0, but was not different than days 50 and 158 . No differences between groups was evident for plasma albumin levels and no group and period interaction was noticed (Figure 2c).

Plasma urea concentration differed between groups showing higher $(\mathrm{p}=0.005)$ levels in control than restricted group (Figure $2 \mathrm{~d}$ ). When compared among periods, higher $(\mathrm{p}<0.001)$ plasma urea levels were observed at $\mathrm{d} 0$ and 158 compared to other measurement days, and an interaction effect $(\mathrm{p}=0.004)$ occurred.

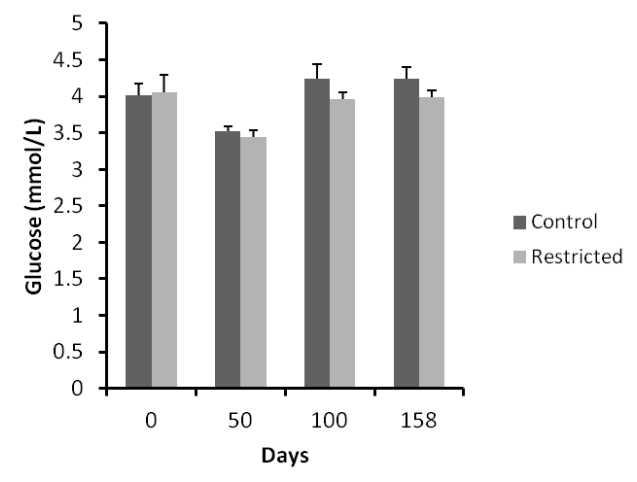

(a)

p-values: Group, NS; Period, 0.001; Group $\times$ Period, NS
Plasma triglyceride levels were not different between the groups (Figure 2e). However, there were period effects showing higher levels $(p=0.001)$ at the start $(0 \mathrm{~d})$ compared to d 100 and 158 , but was not different than $\mathrm{d} 50$, and no interaction between groups and periods was noticed.

The amylase levels in plasma was neither affected by the dietary treatments nor were any period effects observed showing no interaction between groups and periods (Figure 2f).

The AST levels in plasma was higher $(\mathrm{p}<0.05)$ in restricted than control group and there were period effects $(\mathrm{p}=0.002)$ showing higher levels at d 158 than other measurement dates (Figure 2g). The ALT levels in plasma also differed between the groups, showing higher $(\mathrm{p}<0.001)$ levels in restricted than control group, however, no period effects were observed (Figure $2 \mathrm{~h}$ ). An interaction effect ( $\mathrm{p}=$ 0.002 ) occurred between groups and periods with respect to plasma ALT levels.

\section{mRNA expression in liver}

The mRNA expressions for the gluconeogenic enzymes such as PEPCK-C and PC, and visfatin measured by

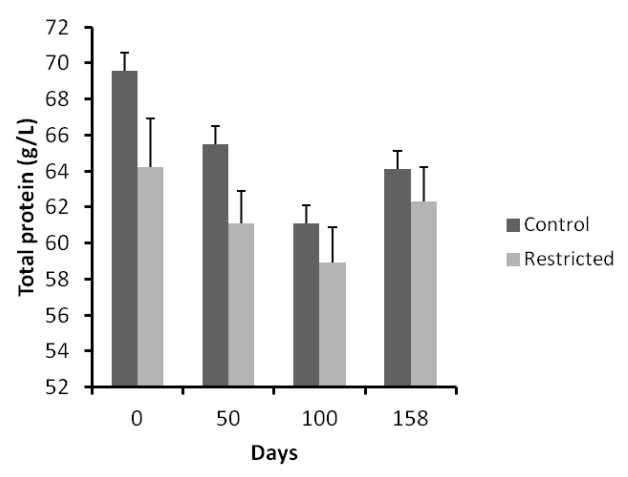

(b)

p-values: Group, 0.035; Period, 0.033; Group $\times$ Period, NS

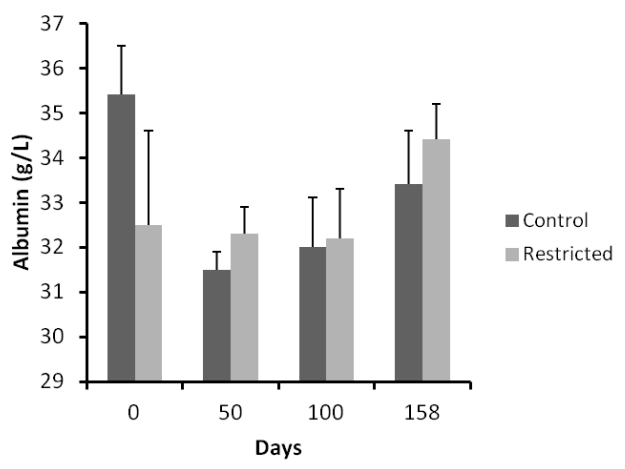

(c)

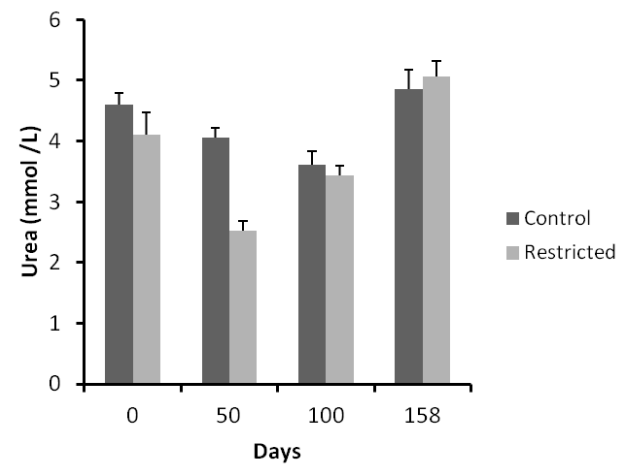

(d)

p-values: Group, 0.05 ; Period, 0.001; Group $\times$ Period, 0.004

Figure 2. i) Effect of limited concentrate feeding on plasma levels of glucose (a), total protein (b), albumin (c), and urea (d). NS, not significant. 


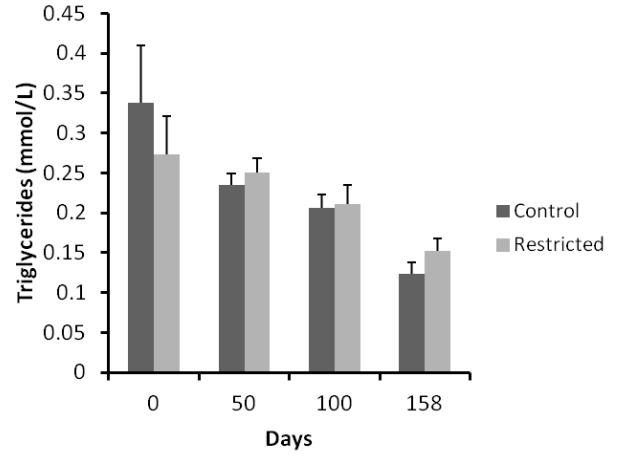

(e)

p-values: Group, NS; Period, 0.001; NS: Group $\times$ Period, NS

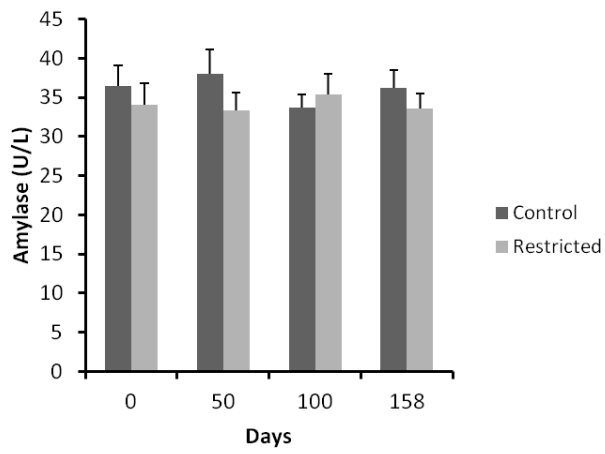

(f)

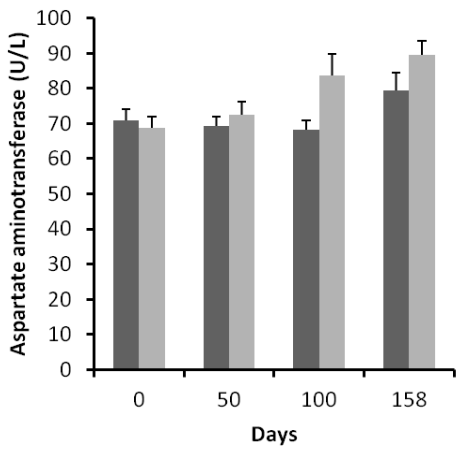

(g)

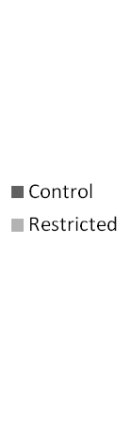

p-values: Group,0.021; Period, 0.002; Group $\times$ Period, NS

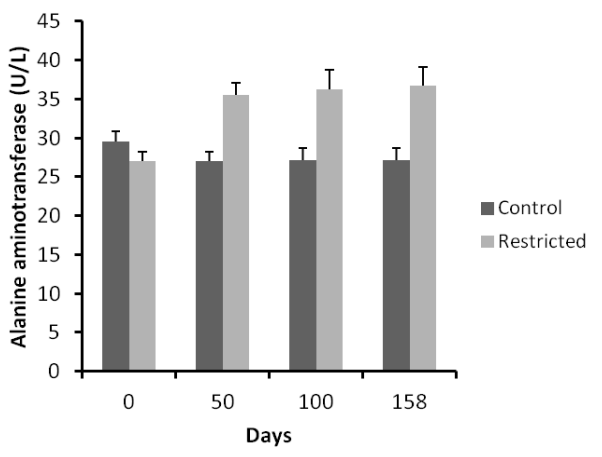

(h)

p-values: Group, 0.001; Period, NS; Group $\times$ Period, 0.002

Figure 2. ii) Effect of limited concentrate feeding on plasma levels of triglycerides (e), amylase (f), aspartate aminotransferase (g), and alanine aminotransferase (h). NS, not significant.

quantitative real-time PCR in liver biopsies showed higher expression $(\mathrm{p}<0.05)$ in restricted group than control demonstrating the effects of diets (Table 5).

\section{DISCUSSION}

The relationship between energy intake and energy retention is nonlinear such that maximum feed efficiency does not occur at maximum intake. Encouraging forage intake is also not beneficial because of lower digestibility of most forages, greater metabolic protein and energy requirements associated with digesting forage (Reynolds et

Table 5. Effect of limited concentrate feeding on mRNA concentrations of phosphoenol pyruvate carboxykinase (PEPCK), pyruvate carboxylase (PC), and visfatin in liver by RT-PCR relative to the reference gene (GAPDH)

\begin{tabular}{lcccc}
\hline Variable & Control $^{1}$ & Restricted & SEM $^{2}$ & p-value \\
\hline PEPCK-C & 0.0308 & 0.0458 & 0.0026 & 0.001 \\
PC & 0.0034 & 0.0070 & 0.0006 & 0.001 \\
Visfatin & 0.0007 & 0.0011 & 0.0001 & 0.041 \\
\hline
\end{tabular}

${ }^{1}$ Averages are based on 10 animals in each group.

${ }^{2} \mathrm{SEM}=$ Standard error of means al., 1991), and higher feed costs per unit of energy as compared to concentrates (Zanton and Heinrichs, 2007). The optimal strategy would be to feed high nutritive value forages to young calves along with concentrate while maintaining ADG. Restricting the concentrate amount to half of the recommended and encouraging more good quality hay consumption in this study resulted in a slower growth compared to control calves. The growth rate of control calves in the current study was similar to that reported earlier for high-concentrate fed calves (Sarker et al., 2010). The intake of forages was higher in restricted group than the control as expected. BW measurements at 10 d interval were not different between groups until the end, however, final BW weight tended to be higher $(\mathrm{p}=0.061)$ in control than restricted group (Table 4, Figure 1). Numerically but non-significantly higher BW was observed in calves in the control than restricted group from 7 th measurement and the trend continued except for final BW. An ADG of greater than 700 to $800 \mathrm{~g}$ for the initial growing period in control calves could be considered appropriate for a small beef breed like Hanwoo. The greater fibre concentration of the restricted diet could have lowered the 
ADG values compared with the control in the present study. The $\mathrm{CP}$ and $\mathrm{ME}$ requirements of the control group were met mostly by the intake of energy-dense concentrate. The higher daily intake of DM and $\mathrm{CP}$ in the control group calves (Table 3) concomitantly resulted in higher ADG and BW gain compared with the restricted group. Thus, the present study depicted restricting concentrate during growing period in slow growing beef calves is not advocated for rearing the calves.

The plasma levels of glucose did not differ between the groups (Figure 2a) and the levels were within the normal range (Lumsden et al., 1980; Fürll, 2005). No interaction effect ( $\mathrm{p}=0.020)$ was noticed for the plasma glucose levels, however, period effects were observed showing lower levels at period 2 than other periods and the levels increased subsequently in both groups. There was an increase in serum glucose levels in both groups with increasing age (period effect, $\mathrm{p}<0.0001$ ), in our earlier study (Lohakare et al., 2012). Haga et al. (2008) reported that plasma glucose levels were lower around weaning $(8 \mathrm{wk})$ but then increased at 13 and 19 wk of age that corresponds well with the present results. The weaning stress along with lower feed intake could be the reason for lower plasma glucose in both groups at this time period. Around weaning, the rates of irreversible loss and recycling of glucose decreased suggesting that glucose is preferably used as the energy source in suckling calves (Hayashi et al., 2006). Higher glucose levels in subsequent periods would suggest that calves in both groups were well adapted to the feeding regime and could have a better ability to utilize glucose.

The plasma levels of total protein varied due to dietary treatments (Figure 2b). Lower levels of plasma total protein in restricted group than control suggested that the concentrate intake was not sufficient to achieve higher levels in this group. No differences between groups were evident for plasma albumin levels (Figure 2c). An increase in protein intake due to higher concentrate intake has been reported to increase serum albumin (Shetaewi and Ross, 1991), but the result in the present study is contradictory.

The plasma levels of urea were influenced by diets and by periods. Also, higher levels were recorded at periods 1 and 4 than periods 2 and 3 but all values were with the normal range (Lumsden et al., 1980; Fürll, 2005). Serum urea concentrations are influenced by a wide variety of interrelated variables including dietary $\mathrm{CP}$ intake and rumen degradability, dietary amino acid composition, protein intake relative to requirement, liver and kidney function, muscle tissue breakdown, and dietary carbohydrate amount and effective rumen degradable protein intake (Eicher et al., 1999). Higher plasma urea levels in control group might be attributed to higher protein degradation which might not have been properly utilized in the rumen. Lower plasma urea and lower plasma total protein levels at period 3 is suggestive of impaired protein degradation but exact reasons remained unclear.

Plasma triglycerides levels in calves in other studies showed no consistent change with age (Sivakanesan and Maraithasan, 1996; Hugi and Blum, 1997), contradictory to the results of the present study. Plasma triglycerides levels were not different between the groups (Figure 2e). However, there were period effects showing higher levels $(p=0.001)$ at the start compared to periods 3 and 4 but were not different from period 2.

Amylase is found in intestinal mucosa and liver as well as in the pancreas. However, the serum amylase level is derived mainly from the pancreas. The amylase levels in plasma was neither affected by the dietary treatments nor were any period effects observed showing no interaction between groups and periods (Figure 2f), demonstrating normal functioning of the pancreas in calves of both the groups.

Aminotransferases acts as a catalyst in connecting the metabolism of amino acids and carbohydrates. Accordingly, changes in their activity in the blood can be a consequence of their increased activity in cells (primarily liver), but also a reflection of cell structure damage. In the liver AST, ALT show high activity and are most often determined if there is a suspicion of acute and chronic liver disease. Increased AST activity in the serum is a sensitive marker of liver damage, even if the damage is of subclinical nature (Meyer and Harvey, 1998; Stojevic et al., 2005). The AST levels in plasma was higher $(\mathrm{p}<0.05)$ in restricted than control group and there were period effects $(p=0.002)$ showing higher levels at 4 th period than other periods (Figure 2g). Kaneko et al. (1997) mention the value of AST activity in cows as $105 \pm 27$ U/L, and AST values reported by Kauppinen (1984) for a group of healthy cows are $65.05 \pm 31.31 \mathrm{U} / \mathrm{L}$. Our values fall in this range and it is considered that the described changes are a reflection of metabolic events.

The ALT levels in plasma also differed between the groups, showing higher $(\mathrm{p}<0.001)$ levels in restricted than control group, however, no period effects were observed (Figure $2 \mathrm{~h})$. An interaction effect $(\mathrm{p}=0.002)$ occurred between groups and periods with respect to plasma ALT levels. Both primary and secondary hepatic disease can cause increased ALT levels, if altered cell membrane permeability or necrosis occurs. Usually ALT values exceed AST values in liver disease. The ALT values in the present study matches well with that reported earlier (Kaneko et al., 1997) of $27 \pm 14 \mathrm{U} / \mathrm{L}$.

The PC and PEPCK enzymes are rate limiting enzymes for gluconeogenesis (Greenfield et al., 2000), and thus play an important role in energy metabolism. It was hypothesized that reduction in feed intake could decrease blood glucose levels in animals in the restricted group and might prompt gluconeogenesis in the liver to meet the 
metabolic glucose requirements, and this was proved in the present study after measuring the expression of gluconeogenic enzymes. The mRNA expressions for the gluconeogenic enzymes such as PEPCK-C and PC measured by quantitative real-time PCR in liver biopsies showed higher expression $(\mathrm{p}<0.05)$ in restricted group than control showing the effects of diets (Table 5). The higher mRNA expression for gluconeogenic enzymes indicates that extra energy requirement through gluconeogenesis in restricted calves might have occurred as plasma glucose levels were within the normal range, although a bit lower than the control group. Results showing increased mRNA expression of visfatin in the restricted than control group also showed glucose metabolism was not normal in these calves and a homeostatic mechanism to restore glucose metabolism might have been prompted in these calves. High inter-individual differences in mRNA expression of gluconeogenic enzymes in cows were recently described by Van Dorland and Bruckmaier (2010) which was also observed in the present study. These authors observed no differences between samples collected from different locations within the liver of one animal. We therefore expected similarities in the samples from repeated liver biopsies from the same animal, but variance among animals in relation to expression might also cause differences between groups. We did not measure the expression of mitochondrial PEPCK-M as it is supposed not to be regulated by metabolic changes in mammals (Hanson and Reshef, 1997) including cattle (Agca et al., 2002).

\section{CONCLUSIONS}

Restricting concentrate was partially compensated by increased intake of forage. Growth intensity was greatly reduced by restricting concentrate intake. Gene expression of the gluconeogenic enzymes and visfatin in the liver of beef calves was affected by the diets. Also, plasma indices showed difference between groups, such that restricting concentrate to the levels in the present study might not be advocated for rearing Hanwoo beef calves.

\section{ACKNOWLEDGEMENTS}

The funding provided by National Research Foundation, Korea under the grant number C 1007297-01-01 (120100382) to carry out this project is gratefully acknowledged. Partial financial support by Institute of Animal Resources at Kangwon National University is also duly acknowledged.

\section{REFERENCES}

Agca, C., R. B. Greenfield, J. R. Hartwell and S. S. Donkin. 2002.
Cloning and characterization of bovine cytosolic and mitochondrial PEPCK during transition to lactation. Physiol. Genomics 11:53-63.

AOAC. 1997. Official methods of analysis. 16th edn. Association of Official Analytical Chemists, Arlington, VA, USA.

Eicher, R., A. Liesegang, E. Bouchard and A. Tremblay. 1999. Effect of cow specific factors and feeding frequency of concentrate on diurnal variations of blood metabolites in dairy cows. Am. J. Vet. Res. 60:1493-1499.

Fukuhara, A., M. Matsuda, M. Nishizawa, K. Segawa, M. Tanaka, K. Kishimoto, Y. Matsuki, M. Murakami, T. Ichisaka, H. Murakami, E. Watanabe, T. Takagi, M. Ayikoshi, T. Ohtsubo, S. Kihara, S. Yamashita, M. Makishima, T. Funahashi, S. Yamanaka, R. Hiramatsu, Y. Matsuzawa and Shimomura I. 2005. Visfatin: a protein secreted by visceral fat that mimics the effects of insulin. Science 307:426-430.

Fürll, M. 2005. Klinische labordiagnostik in der tiermedizin. Spezielle Untersuchungen beim Wiederkäuer. Schattauer, Stuttgart. Germany.

Garrett, W. N. 1979. Relationships among diet, metabolizable energy utilization and net energy values of feedstuffs. J. Anim. Sci. 49:1402-1409.

Girard, J., P. Ferre, J. P. Pegorier and P. H. Duee. 1992. Adaptations of glucose and fatty acid metabolism during perinatal period and suckling-weaning transition. Physiol. Rev. 72:507-562.

Greenfield, R. B., M. J. Cecava and S. S. Donkin. 2000. Changes in mRNA expression for gluconeogenic enzymes in liver of dairy cattle during the transition to lactation. J. Dairy Sci. 83: 1228-1236.

Haga, S., S. Fujimoto, T. Yonezawa, K.Yoshioka, H. Shingu, K. Kobayashi, T. Takahashi, Y. Otani, K. Katoh and Y. Obara. 2008. Changes in hepatic key enzymes of dairy calves in early weaning production systems. J. Dairy Sci. 91:3156-3164.

Hammon, H. M. and J. W. Blum. 1998. Metabolic and endocrine traits of neonatal calves are influenced by feeding colostrums for different durations or only milk replacer. J. Nutr. 128:624632.

Hammon, H. M., S. N. Sauter, M. Reist, Y. Zbinden, C. Philipona, C. Morel and J. W. Blum. 2003. Dexamethasone and colostrum feeding affect hepatic gluconeogenic enzymes differently in neonatal calves. J. Anim. Sci. 81:3095-3106.

Hanson, R. W. and L. Reshef. 1997. Regulation of phosphoenol pyruvate carboxykinase (GTP) gene expression. Annu. Rev. Biochem. 66:581-611.

Hayashi, H., M. Kawai, I. Nonaka, F. Terada, K. Katoh and Y. Obara. 2006. Developmental changes in the kinetics of glucose and urea in Holstein calves. J. Dairy Sci. 89:1654-1661.

Hoffman, P. C., C. R. Simson and M. Wattiaux. 2007. Limit feeding of gravid Holstein heifers: effect on growth, manure nutrient excretion, and subsequent early lactation performance. J. Dairy Sci. 90:946-954.

Hugi, D. and J. W. Blum. 1997. Changes of blood metabolites and hormones in breeding calves associated with weaning. J. Vet. Med. A. 44:99-108.

Kaneko, J. J., W. Harvey and M. L. Bruss. 1997. Clinical Biochemistry of Domestic Animals, 5th edn. Academic Press, San Diego, London, Boston, New York, Sydney, Tokyo, Toronto. 
Kauppinen, K. 1984. ALAT, AP, ASAT, GGT, OCT, activities and urea and total bilirubin concentrations in plasma of normal and ketotic dairy cows. Zbl. Veternarmed. A. 31:567-576.

Korean feeding standard for Korean cattle (Hanwoo). 2002. Ministry of Agriculture and Forestry, National Livestock Research Institute, Rural Development Administration, Suwon, South Korea.

Lemor, A., A. Hosseini, H. Sauerwein and M. Mielenz. 2009. Transition period-related changes in the abundance of the mRNAs of adiponectin and its receptors, of visfatin, and of fatty acid binding receptors in adipose tissue of high-yielding dairy cows. Domest. Anim. Endocrinol. 37:37-44.

Livak, K. J. and T. D. Schmittgen. 2001. Analysis of relative gene expression data using real-time quantitative PCR and the 2(Delta Delta C(T)) method. Methods 25:402-408.

Lohakare, J. D., H. Van der Sand, K. Gerlach, A. Hosseini, M. Mielenz, H. Sauerwein, M. Pries and K. H. Südekum. 2012. Effects of limited concentrate feeding on growth and blood and serum variables, and on nutrient digestibility and gene expression of hepatic gluconeogenic enzymes in dairy calves. J. Anim. Physiol. Anim. Nutr. 96:25-36.

Lumsden, J. H., K. Mullen and R. Rowe. 1980. Haematology and biochemistry reference values for female Holstein cattle. Can. J. Comp. Med. Vet. Sci. 44:24-31.

Meyer, D. J. and J. W. Harvey. 1998. Evaluation of hepatobiliary system and skeletal muscle and lipid disorders. In: Veterinary Laboratory Medicine, Interpretation and Diagnosis (Ed. W. B. Saunders). pp. 157-187.

Reynolds, C. K., H. F. Tyrrell and P. J. Reynolds. 1991. Effects of diet forage-to-concentrate ration and intake on energy metabolism in growing beef heifers: whole body energy and nitrogen balance and visceral heat production. J. Nutr. 121: 994-1003.
Sarker, M. S. K., S. Y. Ko, S. M. Lee, G. M. Kim, J. K. Choi and C. J. Yang. 2010. Effect of different feed additives on growth performance and blood profiles of Korean Hanwoo calves. Asian-Aust. J. Anim. Sci. 23:52-60.

Shetaewi, M. M. and T. T. Ross. 1991. Effects of concentrate supplementation and lasalocid on serum chemistry and hormone profiles in Rambouillet ewes. Small Rumin. Res. 4: 365-377.

Sivakanesan, R. and P. Mariathasan. 1996. Age related changes in some biochemical constituents of blood in growing buffalo calves. Paper presented at: Proceedings of the 2nd Asian Buffalo Association Congress, Manilla Philippines.

Stojevic, Z., J. Pirsljin, S. Milinkovic-tur, M. Zdelar-tuk and B. B. Ljubic. 2005. Activities of AST, ALT and GGT in clinically healthy dairy cows during lactation and in the dry period. Vet. Arhiv. 75:67-73.

Swanson, K. S., N. R. Merchen, J. W. Jr. Erdman, J. K. Drackley, F. Orias, G. N. Douglas and J. C. Huhn. 2000. Technical note: A technique for multiple liver biopsies in neonatal calves. J. Anim. Sci. 78:2459-2463.

Van Dorland, H. A. and R. M. Bruckmaier. 2010. Regional mRNA expression of key gluconeogenic enzymes in the liver of dairy cows. J. Anim. Physiol. Anim. Nutr. 94:505-508.

Van Soest, P. J., J. B. Robertson and B. A. Lewis. 1991. Methods for dietary fiber, neutral detergent fiber, and non-starch polysaccharides in relation to animal nutrition. J. Dairy Sci. 74: 3583-3597.

Zanton, G. I. and A. J. Heinrichs. 2007. The effects of controlled feeding of a high-forage or high-concentrate ration on heifer growth and first-lactation milk production. J. Dairy Sci. 90: 3388-3396. 